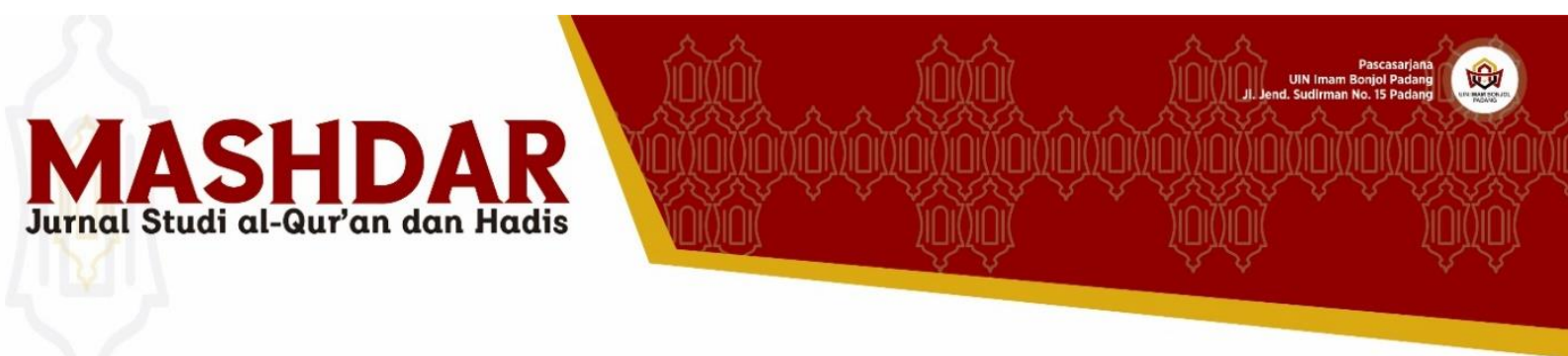

\title{
Evolusi Madrasah Tafsir Al-Qur'an di Mesir: Penelusuran Era dan Tipologi Media
}

\author{
Ulya Fikriyati \\ Institut Ilmu Keislaman Annuqayah \\ (INSTIKA) Sumenep \\ email: ulya.fikriyati@gmail.com
}

\begin{abstract}
Humans are always obsessed with a newness. They are trying to display and apply a newness in various aspects of life. The same practice is also happen in Egyptian exegesis school. Although not as old as the exegesis school in Mecca, Medina, Kufa and Basra, the exegesis school in Egypt are interesting to be examined in reason of its exist from the classical to the contemporary era. The stretched era definitely requires an evolution. This article explores the evolution of media used in delivering Qur'anic interpretation and commentaries along these eras in Egypt. Using a historical approach, the evolution of exegesis school in Egypt can be mapped into three main phases. The classical phase uses the oral and written media (manuscripts), the transitional phase uses printing (magazines/printed books) and electronic media (radio / television), and the contemporary phase uses digital media.
\end{abstract}

Keywords: Egypt; school; transitional; contemporary; media; evolution

(P-ISSN: 2685-1547; E-ISSN: 2685-1555)

Pemalink:

Avaible on https://ejournal.uinib.ac.id/jurnal/index.php/mashdar

\section{PENDAHULUAN}

Salah satu tabiat alamiah manusia adalah menyukai keterhubungan melalui media baru dan terobsesi dengan hal-hal baru. ${ }^{1}$ Kenyataan tersebut menjadi alasan utama mengapa manusia selalu berusaha mengikuti perkembangan media komunikasi sebagai sarana untuk menyampaikan gagasannya. Evolusi media juga bisa kita dapati pada perkembangan madrasah tafsir Al-Qur'an di Mesir.

\footnotetext{
${ }^{1}$ Jessica Pressman, Digital Modernism Making It New in New Media (Oxford: Oxford University Press, 2014), 1.
}

Bahasa Indonesia mengenal kata madrasah sebagai lembaga, sekolah, atau perguruan yang biasanya berdiri di atas landasan agama Islam. $^{2}$ Dalam sejarah penafsiran, istilah madrasat al-tafsìr secara resmi diperkenalkan pertama kali oleh Muhammad Ḥusayn al-Dhahabī. Dalam definisi al-Dhahabī, madrasat al-tafsīr merupakan kumpulan sekelompok orang yang belajar tentang makna-makna AlQur'an dan dipimpin oleh seorang guru.

2 Badan Pengembangan dan Pembinaan Bahasa, "mad.ra.sah," KBBI V (2016), kbbi.kemdikbud.go.id, diakses 12 November 2020. 
Secara resmi, madrasah tafsir baru terlembagakan pada perpotongan era antara sahabat dan tabiin. Kalangan Sahabat sebagai guru, dan kalangan tabiin menjadi murid. ${ }^{3}$ Meski demikian, perlu diingat bahwa cikal bakal madrasah tafsir sebenarnya telah ada sejak era Rasulullah. ${ }^{4}$ Hal tersebut tidak bisa dilepaskan dari keyakinan umat muslim tentang eksistensi Al-Qur'an sebagai petunjuk. Guna menjadikan Al-Qur'an sebagai petunjuk, mutlak diperlukan pemahaman atas $\mathrm{Al}$ Qur'an. Alasan inilah yang melandasi kemunculan madrasah tafsir dalam sejarah umat Islam. Dalam kajian sejarah ilmu tafsir, ada empat madrasah tafsir yang dikenal muncul paling awal yaitu madrasah Makkah, Madinah, Kufah, dan Basrah. $^{5}$

Selain keempat madrasah tafsir tersebut yang semuanya berada di benua Asia, era tafsir klasik juga mencatat ada madrasahmadrasah tafsir lain yang berada di luar benua Asia seperti madrasah tafsir Andalusia $^{6}$ di Eropa dan madrasah tafsir

\footnotetext{
3 Muhammad Husayn al-Dhahabī, Al-Tafsìr wa alMufassirūn (Kairo: Dār Ihyāà al-Turāth al-'Arab̄̄, 1976), vol. I: 101.

${ }^{4}$ Pada awalnya kata midrās-lah yang digunakan untuk menyebut rumah atau tempat yang digunakan dalam proses mempelajari Al-Qur'an. Penulis penulis belum menemukan sumber resmi kapan kata midrās bergeser menjadi madrasat al-tafsīr. Namun, istilah madrasat tafsīr telah jamak digunakan dalam sumber-sumber kajian ilmu tafsir yang semuanya merujuk pada halaqah yang mengajarkan tentang pemahaman Al-Qur'an. Lembaga Madrasat tafsir paling awal secara resmi diketahui diinisiasi oleh para sahabat dan dipopulerkan oleh para murid mereka dari kalangan tabiin. Meski demikian secara de facto embrio awal madrasat al-tafsìr sejatinya telah ada sejak era Rasulullah. Jamāl al-Dīn Muhammad ibn Manzhūr, "midrās," dalam Lisān al- 'Arab (Beirut: Dār alȘādir, 2000), vol.v: 245; Hussein Abdul-Raof, Schools of Qur'anic Exegesis (Oxon: Routledge, 2013), 128; Ulya Fikriyati, "Madrasah Tafsir Virtual di Indonesia Kontemporer: Genealogi dan Kontestasinya di Kanal YouTube," dalam Tafsir Al-Qur'an di Nusantara, ed. Ahmad Baedowi (Yogyakarta: Ladang Kata, 2020).

${ }^{5}$ Al-Dhahabī, Al-Tafsìr wa al-Mufassirūn, vol. I: 105130.

6 Fahd 'Abd al-Raḥmān al-Rūmī, Manhaj alMadrasah al-Andalusiyyah fi al-Tafsīr Sifātuh wa Khașā'isuh (Riyaḍ: Maktabat al-Tawbah, 1997).
}

Mesir $^{7}$ di Afrika. Dibanding beberapa wilayah Timur Tengah yang lain, Mesir memiliki karakter lebih terbuka dan toleran terhadap perbedaan. Setidaknya ada tujuh pilar utama dari tradisi dan letak geografis yang membentuk karakteristik tersebut. ${ }^{8}$ Keterbukaan tersebut menjadi fondasi penting bagi lahirnya berbagai inovasi dalam pengembangan madrasah tafsir di Mesir.

Sebagai salah satu wilayah produktif dalam bidang tafsir Al-Qur'an, Mesir sering menjadi objek kajian penelitian. Salah satunya dilakukan oleh 'Abdullāh Khūrshīd dalam disertasinya yang berjudul Al-Qur'ān wa 'Ulūmuhu fì Mișr (20 $H-358 H)$ pada universitas Cairo. ${ }^{9}$ Disertasi ini membahas tentang sejarah bagaimana Al-Qur'an dan ilmu-ilmu AlQur'an sampai ke wilayah Mesir, bagaimana orang-orang Mesir menulis dan mempelajari Al-Qur'an serta perkembangan ilmu-ilmu Al-Qur'an termasuk tafsir di Mesir klasik. Disertasi Khūrshīd menjadi salah satu sumber utama data artikel ini khususnya dalam mendeskripsikan madrasah tafsir Mesir era klasik.

Tulisan kedua adalah artikel Dzikri Nirwana yang berjudul Peta Tafsir di Mesir Melacak Perkembangan Tafsir Al-Qur'an dari Abad Klasik hingga Modern. ${ }^{10}$ Meski samasama membahas tentang tafsir Mesir, namun titik utama artikel ini berbeda

\footnotetext{
7 'Abdullāh Khūrshīd al-Barrī, Al-Qur'ān wa 'Ulūmuh fī Miṣr $(20 H$ - 358 H) (Kairo: Dār al-Ma‘ārif, 1970).

${ }^{8}$ Tujuh pilar tersebut dibagi menjadi dua: pilar tradisi dan pilar geografis. Pilar tradisi terdiri dari tradisi Fir'aun, Yunani-Romawi Kuno, Koptik dan Islam; adapun pilar geografis meliputi Arab, Afrika dan Laut Tengah. Ah. Fawaid, "Isu-Isu Polemis dalam Diskursus 'Ulūm alQur'ān di Mesir Kontemporer" (Tesis, UIN Syarif Hidayatullah, 2008), 27; Mīlād Hannā, Al-A 'midah alSab'ah li al-Shakhșiyyah al-Mișriyyah (Kairo: Nahḍah Mișr, 1999), 87.

${ }^{9}$ Al-Barrī, Al-Qur'ān wa 'Ulūmuh fì Miṣr (20 H-358 H).

10 Dzikri Nirwana, "Peta Tafsir di Mesir Melacak Perkembangan Tafsir Al-Qur'an dari Abad Klasik hingga Modern," Jurnal Falasifa 1, no. 1 (March 2010): 27-46.
} 
dengan artikel Nirwana. Artikel Nirwana menekankan pergeseran corak dan kecenderungan tafsir-tafsir di Mesir dari era klasik ke modern, sedangkan artikel ini memfokuskan penelitian pada penelusuran ragam inovasi dan pergeseran media yang digunakan dalam madrasah tafsir Mesir dari era klasik hingga kontemporer.

Karya ketiga ditulis oleh Johanna Pink Tradition, Authority, and Innovation in Contemporary Sunn̄̄ Tafsīr: Towards a Typology of Qur'an Commentaries from the Arab World, Indonesia and Turkey ${ }^{11}$ dan Muslim Qur'ānic Interpretation Today. ${ }^{12}$ Pink secara khusus tidak mengkaji tentang madrasah tafsir di Mesir. Pada tulisan pertamanya, Pink memusatkan penelitiannya pada dialektika antara mekanisme penulisan tafsir Al-Qur'an dan hubungannya dengan negara bangsa modern. Pink menjadikan Mesir, Indonesia dan Turki sebagai sampel dalam kajian tersebut. Pada penelitian kedua, Pink menggali tentang media dan ragam tafsir yang muncul pada era kontemporer secara umum. Beberapa data dalam tulisan Pink akan menjadi pelengkap dari artikel ini, khususnya dalam merumuskan ragam madrasah tafsir pada era kontemporer.

Jika pada karya-karya terdahulu tafsir Mesir lebih sering dikaji dari aspek ideologi dan corak keilmuannya, maka artikel ini membidik madrasah tafsir Mesir dari sudut pandang media komunikasi yang digunakannya. Sebuah kajian yang masih sangat minim untuk konteks wilayah Mesir. Untuk melihat perkembangan tersebut, kajian akan dibentangkan dari era klasik (awal

\footnotetext{
11 Johanna Pink, "Tradition, Authority, and Innovation in Contemporary Sunn̄̄ Tafsīr: Towards a Typology of Qur'an Commentaries from the Arab World, Indonesia and Turkey," Journal of Qur'anic Studies 12 (2010): 5682 .

12 Johanna Pink, Muslim Qur'ânic Interpretation Today Media, Genealogies and Interpretive Communities (Bristol: Equinox Publishing, 2019).
}

masuknya Islam ke Mesir hingga sebelum kekalahan Arab atas Israel pada 1967 M) $)^{13}$ hingga era kontemporer (pasca 1967 hingga sekarang). ${ }^{14}$ Tidak semua karya tafsir yang lahir dan ditulis oleh orang Mesir pada rentang tersebut akan dibahas dalam artikel ini. Sebagai gantinya akan dipilih beberapa karya yang mewakili masing-masing perkembangan media yang digunakan dalam madrasah tafsir Mesir.

\section{PERSPEKTIF METODOLOGI}

Tulisan ini bersifat kualitatif dengan model penelitian kajian library research (telaah pustaka). Adapun penkajiannya menitik beratkan kepada kajian era dan tipologi media yang berkembang khususnya di tafsir Mesir.

\section{PEMBAHASAN}

\section{Perkembangan Media dalam Madrasah Tafsir Mesir}

Menelusuri perkembangan media yang digunakan dalam madrasah tafsir di Mesir muntlak menelusuri waktu masuknya Islam ke sana. Sejarah mencatat bahwa Islam pertama kali masuk ke Mesir pada masa kekhalifahan Umar ibn al-Khaț̣āab ${ }^{15}$ di bawah komando panglima 'Amr ibn al'Āṣ pada tahun 18 H. ${ }^{16}$ Dalam pasukan 'Amr ibn al-'Āṣ terdapat beberapa sahabat yang memiliki catatan Al-Qur'an. Di antara para sahabat tersebut ada Abdullāh ibn Sa'd ibn Abī Sārah, 'Uqbah ibn 'Āmir, Abdullāh ibn 'Amr ibn 'Āṣ, Ghurfah ibn Ḥārith al-Kindī, dan Wardan (budak 'Amr). Setelah Mesir bergabung dalam wilayah kekuasaan khalifah 'Umar, beberapa sahabat yang tergabung dalam barisan

\footnotetext{
${ }^{13}$ Fawaid, "Isu-Isu Polemis," 50.

${ }^{14}$ Ibrahim Abu Rabi', The Blackwell Companion to Contemporary Islamic Thought (Oxford: Blackwell Publishing, 2006).

${ }^{15}$ Nāṣir al-Anșārī, al-Mujmal fī Tārīkh Miṣr al-Nuẓum al-Siyāsiyah wa al-Idāriyyah (Kairo: Dār al-Syurūq, 1993), 95.

16 'Abd al-Karīm al-Ka' bī, Mawsū' àt al-Tārīkh alIslāmī 'Așr al-Khulafă' al-Rāshidīn (Amman: Dār Usāmah, 2009), 139.
} 
pasukan menetap di Mesir. Mereka mengajarkan Al-Qur'an dan maksudmaksud yang terkandung di dalamnya pada warga Mesir sebelum muṣhaf 'Uthmānī resmi diterbitkan. ${ }^{17}$

Bahasan berikut akan memaparkan perkembangan madrasah tafsir di Mesir dari perspektif evolusi media yang digunakannya.

\section{Fase Klasik dalam Madrasah Tafsir Mesir}

Fase pertama disebut klasik karena hanya menggunakan media tradisional dalam proses penyampaian makna-makna Al-Qur'an. Fase klasik dimulai dari awal Islam masuk ke Mesir pada tahun $18 \mathrm{H}^{18}$ (sekitar $639 \mathrm{M}$ ) hingga sebelum mesin cetak pertama masuk ke Mesir pada 1819 M. ${ }^{19}$ Dibanding dua fase lainnya, fase klasik ini terbentang paling panjang, sekitar 1.180 tahun. Pada fase klasik hanya ada dua media yang digunakan dalam proses transformasi makna-makna AlQur'an di madrasah tafsir Mesir. Dua media tersebut ialah media lisan dan media tulisan tangan.

\section{Media Lisan}

Dalam sejarah manusia, menyampaikan suatu informasi melalui lisan dan dihapalkan di luar kepala merupakan teknik paling tua dalam proses belajar mengajar. Hal yang sama juga dapat dicermati pada sejarah madrasah tafsir di berbagai belahan dunia seperti Bosnia, India dan Timur Tengah, baik pada era Rasulullah ataupun pada era sahabat yang berpotongan dengan tabiin besar. ${ }^{20}$ Tradisi

17 Al-Barrī, Al-Qur'ān wa 'Ulūmuh fì Miṣr (2O H $358 \mathrm{H}), 13$.

${ }^{18} \mathrm{Al}-\mathrm{Ka}$ ' bī, Mawsū 'àt Al-Tārīkh, 139.

${ }^{19}$ Fawzi M. Tadrus, "Printing in the Arab World with Emphasis on the Būlāq Press in Egypt," quspace.qu.edu.qa (1982): 61-77, diakses 6 Agustus 2020.

${ }^{20}$ Andreas Görke, "Redefining the Borders of Tafsìr: Oral Exegesis, Lay Exegesis and Regional Particularities," dalam Tafsìr and Islamic Intellectual History Exploring the Boundaries of a Genre, ed. Andreas Görke dan masyarakat Arab saat Al-Qur'an diturunkan dapat dipastikan memainkan peran penting dalam populerisasi tradisi lisan dalam pengajaran tafsir. Masyarakat Arab terbiasa menghafalkan apapun yang mereka anggap penting. Bukan hal aneh ketika seseorang dapat menghafal pohon keturunannya hingga melampaui sepuluh generasi. Sejatinya, penghargaan atas tradisi lisan dan hafalan tidak hanya dimiliki oleh bangsa Arab. Socrates sebagaimana dikutip oleh McLuhan bahkan mengkritik penggunaan alfabet karena dianggap menumpulkan hafalan dan memori:

"Penemuan alfabet akan menciptakan kelupaan dalam jiwa seorang pembelajar karena mereka tidak akan memfungsikan memori mereka. Mereka akan mempercayai karakter-karakter yang ditulis dan tidak mengingat substansi dari karakter-karakter tersebut. Kamu tidak akan memberikan kebenaran pada murid-muridmu, tetapi hanya memberikan apa yang tampak seolah sebuah kebenaran. Mereka akan menjadi pahlawan dalam banyak hal tetapi mereka tidak akan belajar apapun. Mereka akan terlihat tahu segalanya namun secara umum mereka tidak tahu apapun." 21

Selintas, pernyataan Socrates terkesan sarkastik, namun jika kita mau jujur, sering kali kemudahan yang ditawarkan oleh teknologi mengurangi kemampuan natural manusia itu sendiri. Dalam konteks madrasah tafsir yang dikaji, tradisi penyampaian secara lisan oleh guru dan menghafal oleh murid dapat dijumpai dalam fase klasik madrasah tafsir Mesir. Para sahabat yang turut serta dalam penaklukan Mesir atau beberapa yang

\footnotetext{
Johanna Pink (Oxford: Oxford University Press, 2014), 74.

${ }^{21}$ Marshall McLuhan, The Medium Is the Massage an
} Inventory of Effect (New York: Gingko Press, 2001), 113. 
tinggal setelah penaklukan tersebut mengajarkan Al-Qur'an beserta maknamaknanya dalam bentuk lisan. Tafsir yang dimaksud adalah pemaknaan sederhana dari beberapa kosakata dari ayat AlQur'an.

Mesir telah dikenal sebagai salah satu wilayah dengan tradisi tulis paling tua di dunia, 22 namun dalam konteks madrasah tafsir, belum ditemukan bukti tertulis terkait keberadaan kodek dari generasi Islam pertama di Mesir. Catatan yang ada biasanya didapatkan dari generasi kedua atau ketiga yang mendapatkan tafsir tersebut dalam bentuk riwayat dan dihafal secara berjenjang dari satu generasi ke generasi yang lain. Meski dalam beberapa sumber induk ilmu Al-Qur'an disebutkan keberadaan media tertulis dari madrasah tafsir klasik di Mesir, namun manuskrip tafsir tersebut tidak dapat dipastikan apakah memang benar-benar ada wujud tertulisnya atau tidak.

Akar madrasah tafsir Mesir klasik dapat ditarik hingga madrasah tafsir Makkah yang diasuh oleh Ibn al-'Abbās. Hal tersebut dapat disimpulkan dari nama para sahabat yang berperan dalam perkembangan awal madrasah tafsir Mesir seperti 'Abdullāh ibn 'Amr ibn al-'Āṣ (w. $56 \mathrm{H}$ ) dan 'Abdullāh ibn al-'Abbās (w. 68 $\mathrm{H})$ atau para tabiin seperti Mujāhid ibn Jabr (w. 103 H) dan 'Ikrimah ibn Abī Jahl (w. $105 \mathrm{H}) .{ }^{23}$

Di antara tokoh-tokoh yang menggunakan media lisan pada madrasah tafsir klasik di Mesir adalah:

1. 'Ațā' ibn Dīnār al-Hudhalī (w. 126 H)

Ațā' ibn Dīnār al-Hudhalī adalah seorang tokoh Mesir dalam bidang hadits dan tafsir. Ia memiliki kitab tafsir yang

22 Shelton A. Gunaratne, Paper, Printing and the Printing Press (London, New Delhi: Thousand Oaks, 2001); al-Anșārī, al-Mujmal fī Tārīkh Miṣr, 5.

${ }^{23}$ Nirwana, "Peta Tafsir," 29. berisi riwayat-riwayat dari Sa ${ }^{‘} \bar{i} d$ ibn Jubair. $^{24}$ Riwayat-riwayat yang berisi penafsiran Al-Qur'an tersebut kemudian diajarkan oleh 'Ațā' ibn Dīnār kepada orang-orang Mesir, khususnya para muhaddith Mesir. Di antara para Muhaddith tersebut adalah 'Abdullāh ibn Lahī'ah' ${ }^{25}$ alMiṣrī, Sa ‘̄id ibn Abī Ayyūb, dan Haywah ibn Shuraih yang menyampaikan riwayatnya kepada di antaranya Ibnu Bukair, Al-Hāfiẓ al-Marūzī 'Abdullāh ibn al-Mubārak. Dari merekalah 'Abdurrahmmān ibnu Abī Hātim meriwayatkan hadith-hadith yang berisi riwayat dari 'Ațā' ibn Dīnār kemudian mengumpulkannya menjadi sebuah kitab tafsir yang lebih dikenal dengan tafsir Ibn Abī Ḥātim. ${ }^{26}$

2. 'Ubaid ibn Suwayyah al-Anșārī (w. 135 $\mathrm{H})$,

Tokoh kedua yang dikenal juga sebagai tokoh tafsir Mesir periode klasik adalah 'Ubaid ibn Suwayyah al-Anșārī. Ia dikenal sebagai orang yang șāliḥ, fāḍil, dan thiqqah. Ia meriwayatkan banyak hadith yang berisi tentang tafsir dari Sabī'ah al-Aslamiyyah, dan juga Abdurraḥmān ibn Hujairah yang meriwayatkan dari 'Abdullāh ibn 'Amr ibn al-Āṣ. Menurut Ibnu Ḩajar, 'Ubaid ibn Suwayyah memiliki tafsir Al-Qur'an,27 sayangnya tidak satupun catatan tafsirnya yang dapat diakses saat ini sehingga judul tafsirnya juga tidak dapat dipastikan secara jelas. ${ }^{28}$

24 Khayr al-Dīn ibn Maḥmūd al-Zarkalī, al-A 'tām (Beirut: Dār al-'Ilm li al-Malāyīn, 2002), vol. IV: 235.

${ }^{25}$ Ibn Lahī'ah yang dimaksud di sini adalah Ibn Lahī`ah yang terkenal ke-tsiqqah-annya, bukan Ibn Luhay'ah yang dikenal sebagai perawi yang lemah. AlKhatīb al-Baghdādī, Talkhīṣ al-Mutashābih fi al-Rasm wa Himāyah mā Ashkala minhu 'an Bawādir al-Tașhīf wa alWahm (Damaskus: Sakīnah al-Shihābī, 1985), vol.I: 50.

26 Al-Barrī, Al-Qur'ān wa 'Ulūmuh fì Miṣr (20 H $358 \mathrm{H}), 287$.

${ }^{27}$ Ibn Hajar al-'Asqalānī, Tahdhīb al-Tahdhīb (Kairo: Dār al-Hadìth, 2002), vol. VII: 231.

${ }_{28}$ Al-Barrī, Al-Qur'ān wa 'Ulūmuh fì Miṣr (20 H$358 \mathrm{H}), 299$ 
3. 'Abdullāh ibn Wahb (125-197H)

Jika kedua tokoh sebelumnya dikenal sebagai sheikh kabìr dalam tradisi tafsir Mesir era awal Islam, maka 'Abdullah ibn Wahb dikenal sebagai sosok pemuda intelektual Mesir klasik. Ketika masih berusia 23 tahun, ia mulai merantau ke Madinah, ibukota kekhilafahan Islam kala itu, untuk mendalami berbagai disiplin ilmu seperti hadith, fiqh, qirā'àt, dan tafsir. ${ }^{29}$ Karena jiwa petualangnya yang begitu besar, 'Abdullāh ibn Wahb tidak pernah tergesa-gesa dalam mempelajari apapun. Ia selalu berusaha untuk mendalami apa yang ia pelajari. Bahkan, rasa rindunya akan negeri sungai Nil tidak lantas menghalanginya untuk berlamalama menuntut ilmu di Madinah. Untuk disiplin ilmu tafsir, ia berguru kepada 'Abdurrahmān ibn Zaid, dan untuk bidang fiqh, ia berguru kepada imam Mālik ibn Anas. Ia tinggal di Madinah hingga gurunya, imam Mālik, meninggal. Ia juga menimba ilmu dari berbagai kota lainnya seperti Mekkah, dan Irak. Di antara para gurunya adalah Ibnu Juraij (w.149), Sufyān al-Thaurī (w.161), Sufyān ibn 'Uyainah (w.198).

Sedangkan guru-guru 'Abdullāh yang berasal dari Mesir sendiri adalah 'Amru ibn al-Hārith (w.148), Haiwah ibn Shuraih (w.158), Ibnu Lahī'ah (w.174), al-Laith ibn Sa'ad (w.175). selain dikenal sebagai sosok yang terpercaya, Abdullāh ibn Wahb juga dikenal sebagai hăfiz, mujtahid yang tidak suka mentaqlid siapapun dan sekaligus seorang yang sangat zuhud. ${ }^{30}$

4. 'Abdullāh ibn Ṣālị (137 - 223 H)

Pada awalnya, 'Abdullāh ibn Șāliḥ adalah sekretaris al-Laith ibn Sa'ad (w. 175 H). Akan tetapi, ia tidak hanya mencatat

\footnotetext{
${ }^{29}$ Ibid., 300.

${ }^{30}$ Muḥammad ibn Ahmad al-Dhahabī, Tadhkirat AlHuffāz (Beirut: Dār al-Kutub al-'Ilmiyyah, 1998), vol. I: 222.
}

riwayat-riwayat ataupun ilmu yang ia dapatkan dari al-Laith, tetapi juga meriwayatkan apa yang ia catat serta meneruskannya kepada banyak tokoh yang berkunjung ke Mesir. Seperti yang dinyatakan oleh imam Ahmad ibn Hanbal sebagaimana dituliskan oleh al-Suyūṭi: “Di Mesir, ada sebuah kitab tafsir yang berisi riwayat dari $\mathrm{Mu}$ 'āwiyah ibn Șāliḥ, jika ada salah satu dari kalian yang berkunjung ke Mesir, maka salinlah". ${ }^{31}$ Sayangnya tidak ada keterangan apa nama lengkap dari kitab tafsir ini. Ketika al-Bukhārī berkunjung ke Mesir antara tahun 210 $219 \mathrm{H}$, iapun meriwayatkan kitab tafsir tersebut dari 'Abdullāh ibn Șāliḥ. Demikian juga Ibn Mājah ketika berkunjung ke Mesir pada tahun 215 H, dan Ibn Abī Hātim alRāzī yang mengunjungi Mesir pada tahun $277 \mathrm{H}$, mereka meriwayatkan tafsir dari 'Abdullāh ibn Șāliḥ. ${ }^{32}$

Berbeda dengan beberapa tokoh tafsir Mesir era awal Islam yang memiliki lebih dari satu jalur riwayat, 'Abdullāh ibn Șāliḥ, hanya memiliki satu jalur periwayatan tafsir, yaitu dari Al-Layth ibn Sa'ad dari Mu'āwiyah ibn Ṣāliḥ dari 'Alī ibn Abī Ṭalhah dari Ibnu 'Abbās. ${ }^{33}$ Dengan demikian, untuk menelusuri hadith yang berisi tafsir dari riwayat 'Abdullāh ibn Şālīh, kita dapat merujuk kepada kitab Șahīḥ al-Bukhārī yang meriwayatkan langsung darinya, atau pun Tafsīr ibn Abī Haatim yang meriwayatkan melalui

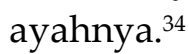

Selain empat tokoh tersebut, Abū Shuhbah menyebutkan dua tokoh lain. Kedua tokoh tersebut bahkan disebut sebagai tokoh paling terkenal dalam penyampaian riwayat tafsir lisan di madrasah Mesir klasik. Keduanya ialah

\footnotetext{
31 Jalāl al-Dīn al-Suyūṭị, al-Itqān fì 'Ulūm al-Qur'ān (Kairo: Dār al-Hadīth, 2004), vol. II: 496.

32 Al-Barrī, al-Qur'ān wa 'Ulūmuh fì Miṣr (2O H $358 \mathrm{H}), 387$.

${ }^{33}$ Ibid., 389.

${ }^{34}$ Ibid.
} 
Abū al-Khair Marthad ibn 'Abdillāh alYaznī (w. 90 H) dan Yazīd ibn Abī Hubayb al-Azdī (w. 128 H). ${ }^{35}$

\section{Media Tulisan}

Secara faktual, tidak dapat dipastikan secara tegas kapan media tulis digunakan dalam madrasah tafsir di Mesir. Dalam pembahasan tentang madrasah tafsir di Syam dan Mesir, Aḥmad ibn Mușțafā alFarrān menjelaskan bahwa media tulis sudah digunakan dalam madrasah tafsir Mesir sejak era kepemimpinan 'Abd al'Azīz ibn Marwān (w. 86 H). Dia melakukan korespondensi dengan Sa'īd ibn Jubair tentang tafsir kata-kata gharīb (asing/tidak lumrah digunakan dalam keseharian) yang ada dalam Al-Qur'an. ${ }^{36}$ Akan tetapi, bukti fisik kumpulan surat tersebut tidak dapat ditemukan untuk diteliti lebih lanjut. Bukti fisik paling awal dari penggunaan media tulis dalam tradisi madrasah tafsir Mesir adalah tafsir Ahkām al-Qur'ān yang ditulis oleh Muhammad ibn Idrīs al-Shāfi'ī $(150$ - $204 \mathrm{H})$ yang disusul oleh tafsir Ma'ānī al-Qur'ān milik Abū Ja 'far al-Naḥhās (w. 338 H). ${ }^{37}$

Media tulis yang menjadi fase lanjutan dalam madrasah tafsir klasik di Mesir tidak berarti menggeser media lisan. Sebaliknya, media tulis digunakan sebagai pelengkap dari media lisan yang telah lebih dulu digunakan. Hal yang sama juga terjadi pada media-media lainnya, baik cetak, elektronik, maupun digital sebagaimana yang akan dijelaskan pada paparan berikutnya.

\section{Fase Transisi}

Fase transisi merupakan fase kedua dalam evolusi media pada madrasah tafsir

35 Muhammad Abū Shuhbah, al-Isrā'īliyyāt wa alMaw d̄u 'āt fī Kutub al-Tafsīr (Kairo: Maktabah al-Sunnah, 2003), 71.

${ }^{36}$ Aḥmad Mușțafā al-Farrān, Tafsìr al-Imām al-Shāfi ‘ (Arab Saudi: Dār Tadmuriyyah, 2006), 23.

37 Al-Barrī, al-Qur'ān wa 'Ulūmuh fì Miṣr (20 H$358 \mathrm{H}), 399$.
Mesir. Penamaan tersebut didasarkan pada masa peralihan dari media tradisional (tanpa menggunakan alat rumit) ke media kontemporer (melibatkan alat yang lebih rumit). Fase transisi berjalan lebih pendek dibanding fase klasik. Fase ini merentang selama 173 tahun dari 1891 (awal digunakannya mesin cetak di Mesir) hingga 1992 (awal masuknya internet di Mesir). Media yang digunakan pada fase transisi dapat dibedakan menjadi dua: media cetak dan media elektronik. Media cetak terdiri dari buku-buku yang dicetak pada percetakan dan tulisan-tulisan pendek yang dimuat dalam majalah atau koran, sedangkan media elektronik direalisasikan dalam bentuk siaran radio dan televisi.

\section{Media Cetak}

Media cetak pertama yang digunakan sebagai media transformasi tafsir pada madrasah tafsir Mesir adalah buku. Percetakan buku pertama di Mesir adalah al-Mațba'ah al-Ahliyyah. Percetakan ini dibangun antara tahun 1819-1821 M pada kekuasaan Muhammad 'Alī (1805 - 1849 M). ${ }^{38}$ Beberapa waktu kemudian, percetakan ini dipindah ke daerah Būlāq, dekat dengan Nil sehingga lebih dikenal dengan nama percetakan Būlāq. Selain dikenal dengan nama Būlāq, percetakan pertama tersebut juga dikenal dengan almațba'ah al-Amīriyyah, al-Mìriyyah, mațba'ah al-Hāj Muhammad 'Alī Bāshā dan lain-lain. ${ }^{39}$

Percetakan Būlāq menjadi awal baru bagi perkembangan media dalam madrasah tafsir Mesir. Hal tersebut diketahui dari ribuan naskah dan buku yang dicetak paling awal pada percetakan

${ }^{38}$ Fawzi M. Tadrus, "Printing in the Arab World with Emphasis on the Būlāq Press in Egypt," quspace.qu.edu.qa (1982): 61, diakses 5 Agustus 2020.

39 Maḥmūd Muḥammad al-Ṭanāḥī, "Awā'il alMaṭū'āt al-'Arabiyyah Fī Miṣr," dalam Tārīkh al-Ṭibā 'āh al-'Arabiyyah hattā Intihā' al-Qarn al-Tāsi' 'Ashar, vol. 1 (Abu Dhabi: Cultural Foundation Publications, 1995), 356. 
Būlāq di antaranya adalah buku-buku tafsir. Meski yang dicetak bukan karyakarya tafsir yang diproduksi oleh tokohtokoh Mesir seperti tafsir Jāmi al-Bayān karya Ibn al-Jarīr al-Ṭabarī, Mafātīḥ alGhayb karya Fakhr al-Dīn al-Rāzī dan Rūḥ al-Ma 'ānì yang ditulis oleh al-Alūsīi, ${ }^{40}$ akan tetapi pengaruhnya terhadap perkembangan media tafsir tidak dapat dipungkiri. Karya-karya tafsir yang ditulis setelah tahun 1821 dapat dipastikan lebih banyak dicetak secara massif. Hal tersebut membuka model baru dari madrasah tafsir fase sebelumnya. Jika sebelumnya hanya menggunakan hafalan dan tulisan yang mutlak membutuhkan guru secara langsung, maka pada era media cetak, madrasah tafsir mengalami perluasan. Seseorang bisa belajar tafsir dengan memiliki buku-buku tafsir yang dicetak secara umum. Namun demikian, tradisi halaqah untuk mempelajari tafsir di masjidmasjid Mesir tidak banyak berubah. Perubahan tersebut terlihat dari penampakan zahirnya. Jika dulu, para murid tafsir harus menghafalkan atau mencatat apa yang disampaikan gurugurunya secara lisan, maka pada era cetak mulai bergeser menjadi guru menjelaskan karya-karya tafsir yang telah dicetak, dan para murid mengikuti penjelasan tersebut sembari mengamati teks dari naskah cetak yang telah mereka miliki.

Media cetak yang mempengaruhi madrasah tafsir Mesir tidak hanya lahir dari percetakan-percetakan buku, tetapi juga dari koran dan majalah yang dapat dibaca oleh masyarakat umum. Jika ditelusuri melalui sejarah jurnalistik Mesir, koran pertama yang terbit di Mesir adalah Le Courrier de l'Egypt tertanggal 28 Agustus 1798. ${ }^{41}$ Meski koran telah ada sejak akhir abad 18, tetapi penggunaan media cetak

\footnotetext{
${ }^{40}$ Ibid., 359.

${ }^{41}$ Ibrāhīm 'Abduh, Tārīkh al-Ṭibā' ah wa al-Șahafah fì Miṣr Khilāl al-Hamlah al-Faransiyyah 1798-1801 M (Jamāmīz: al-Maṭba‘ah al-Namūdhajiyyah, 1949), 59.
}

sebagai madrasah tafsir Al-Qur'an di Mesir baru tercatat sekitar akhir abad 19. Majalah al-Manār yang terbit sejak Februari 1898 M/Syawwal $1315 \mathrm{H}$ besar kemungkinan adalah madrasah tafsir pertama di Mesir yang memfungsikan media cetak majalah. Jika merujuk pada isi majalah al-Manār, Rashīd Riụā terlihat mulai mempopulerkan tafsir dalam lingkup tema-tema tertentu. Misalnya dalam rubrik al-Qawl al-Faṣl yang membahas tentang bagaimana mengupayakan kesejahteraan umat. Riḍā memaparkan berbagai ayat Al-Qur'an yang memerintahkan manusia untuk melintasi berbagai belahan dunia dan memikirkan apa yang dilihatnya, berusaha untuk menemukan berbagai hal baru dengan akalnya, tidak berpangku tangan, menguatkan tali persaudaraan antara kalangan kaya dan kalangan miskin, dan lain-lain. ${ }^{22}$ Dalam bagian lain, Riḍā mengkritik penyebutan "orang kafir" atas penganut agama di luar Islam dalam interaksi sosial di masyarakat. Pembahasan tentang hal itu juga tidak lepas dari proses pemaknaan ayat-ayat Al-Qur'an. ${ }^{43}$

Sekitar tahun 1950-an Muhammad Abū Zahrah juga mempublikasikan tafsir AlQur'an pada majalah Islami yang kemudian dilanjutkan hingga surah kedua puluh tujuh dari Al-Qur'an. ${ }^{44}$ Besar kemungkinan sejumlah tafsir lain juga dipublikasikan pada media cetak seperti penggalan tulisan Amīn al-Khūlī yang kemudian dihimpun pada bukunya Min Hudā al-Qur'ān. ${ }^{45}$ Hal tersebut membuka

\footnotetext{
${ }^{42}$ Muḥammad Rashīd Rị̣ā, Mujallad al-Awwal min al-Manār (Kairo: al-Manār, 1325), 31-46.

${ }^{43}$ Ibid., 14-19.

${ }^{44}$ Pink, "Tradition, Authority," 57.

${ }^{45}$ Min Hudā al-Qur'ān adalah seri dari tulisan Amīn al-Khūli yang terdiri dari tiga judul: Al-Qādah wa alRusul, Min Amwālihim, dan F̄̄ Ramaḍān. Dalam ketiga buku tersebut, al-Khūlī menuliskan tanggal yang berbedabeda untuk masing-masing tulisan pendek. Besar kemungkinan tulisan tersebut telah diterbitkan dalam majalah al-Adab yang dikelolanya. Sayangnya penulis belum mendapatkan bukti jelas tentang hal tersebut meski pernah mendengar dari salah seorang pengkaji Al-Qur'an tentangnya. Karakter singkat pada masing-masing tema
} 
ragam baru dari madrasah tafsir dan tafsir itu sendiri. Madrasah tafsir tidak lagi dibatasi oleh ruang dan waktu yang rigid, tetapi definisi madrasah tafsir mulai bergeser menjadi lebih luas: wadah untuk mempelajari makna dan kandungan AlQur'an. Jika memperhatikan karakteristik media yang digunakan dalam penyebarluasan tafsir, madrasah tafsir dengan pengertian luas ini justru lebih sesuai untuk mengakomodir madrasah tafsir pada era selanjutnya. Pengertian madrasah tafsir yang mengalami ekspansi mau tidak mau juga berimbas pada munculnya ragam tafsir baru. Tafsir tidak selalu disampaikan dalam format akademik. Kadang kala tafsir dapat dikenalkan dalam bentuk yang lebih populis dan dapat dimengerti dengan mudah oleh kalangan umum. Pada tataran tersebut, batasan antara tafsir akademik dan tafsir populer menjadi sangat samar dan tidak jelas. ${ }^{46}$ Pergeseran jenis dan media tafsir ini tidak dapat dilepaskan dari "pasar" tafsir itu sendiri. Sebagai petunjuk bagi siapa saja, akses atas Al-Qur'an dan tafsirnya tidak seharusnya dimonopoli oleh kalangan tertentu. Akses tersebut harus dibuka seluas-luasnya bagi siapapun yang ingin mendekati Al-Qur'an melampaui batasan ruang dan waktu. Suatu keadaan yang dimungkinkan karena kemajuan teknologi.

\section{Media Elektronik}

Media elektronik seperti radio dan televisi merupakan lanjutan dari media cetak yang telah lebih dulu ada pada fase transisi. Mesir mulai mengenal siaran radio sejak 1920-an. Akan tetapi sempat terhenti dan secara resmi dibuka kembali pada 31 Mei 1934 melalui saluran radio pertamanya

kecil dari bahasan tentang Al-Qur'an dapat dilihat di antaranya pada: Amin al-Khūlī, Min Hudā Al-Qur'ān fì Ramadān (Kairo: Al-Hay'ah al-Miṣriyyah al-'Āmmah li al-Kitāb, 1987).

${ }^{46}$ Pink, Muslim Qur'ânic, 84.
al-Idhā'ah al-Mișriyyah. ${ }^{47}$ Dua puluh enam tahun kemudian, siaran televisi pertama di Mesir resmi mengudara tepat pada 21 Juli $1960 .{ }^{48}$ Sebagaimana sarana yang tersedia sebelumnya, radio dan televisi juga digunakan sebagai media madrasah tafsir Al-Qur'an di Mesir.

Mesir menyiarkan program Al-Qur'an pertama kali pada 25 Maret 1964 di saluran Idhā'at al-Qur'ān al-Karìm. Pada awalnya, saluran ini hanya menyiarkan tilawah AlQur'an sepanjang hari, hingga pada 1966 mulai ada penambahan program siaran semisal Hadìth al-Rūḥ, al-Dīn al-Mu'ämalah dan al-Qāmūs al-Islāmī. Pada perkembangan berikutnya, program tafsir Al-Qur'an mulai disiarkan dengan nama Wamdah Tafsìriyyah. Narasumber program ini di antaranya adalah syeikh Muhammad Mutawallī al-Sha'rāwī dan syeikh Muhammad Sayyid Tanțāwīi, ${ }^{49}$ syeikh Sya ‘bān al-Ṣayyād, ${ }^{50}$ dan lain-lain.

Ketika syeikh Mūhammad Sayyid Ṭanțāwī menjadi Grand Syeikh di Al Azhar, beliau juga rutin mengisi siaran radio berjudul Al-Tafsìr al-Mubassat li Āyāt al-Dhikr al-Hakìm yang juga disiarkan oleh Idhā'at al-Qur'ān al-Karìm. Sayangnya tidak ada keterangan kapan tepatnya kedua program tersebut mulai disiarkan secara rutin oleh Idhā'at al-Qur'ân al-Karìm.

Karakter utama dari tafsir Al-Qur'an dengan media radio yang disiarkan oleh

\footnotetext{
${ }^{47}$ Umaymah Su'ūdī, "Al-Idhā'ah al-Mișriyyah Shāhid 'alā Tārīkh Mișr," al-Hay'ah al- 'Āmmah li al-Isti 'lāmāt Jumhüriyyat Mișr al-'Arabiyyah, 17 Februari, 2019, https://www.sis.gov.eg/Story/182829? lang=ar, diakses 6 Agustus 2020.

48 Aḥmad 'Izzat, ed., Al-Idhā'ah Wa al-Tilifziyyūn Dirāsah Fì I'lām al-Sultah (Kairo: Association for Freedom of Thought and Expression (AFTE), 2012), 12.

49 Aḥmad 'Ādil, "Assasahā Shā'ir 'al-Nahr alKhālid'... Idhā'at al-Qur'ān al-Karīm 'Mi'rāj al-Īmān 'abra al-Athīr,", al-Ahrām, March 25, 2018, http://gate.ahram.org.eg/News/1855706.aspx, diakses 5 Agustus 2020.

50 'Abdullāh 'Abd al-'Aẓim, Wamḍah TafsìriyyahIdhā'at al-Qur'ān al-Karìm-Min al-Qähirah al-Syaykh (Kairo, 2019), https://youtu.be/DSDYisaq_lo, diakses 6 Agustus 2020.
} 
Idhā'at al-Qur'ān al-Karìm adalah singkat. Sebelum tafsir dimulai sering dibacakan ayat: "afalā yatadabbarūn al-Qur'ān wa lau kāna fì..." atau "fa qad yassarnā al-Qur'āna li al-dhikr...", kemudian dilanjutkan dengan "mā al-maqșūd min qawlih ta 'âlā... Imā alhaqīqat qawlih ta 'ālā..." (Apa maksud dari firman Allah ta'ala.../apa hakikat makna dari firman Allah ta'ala...). Tafsir yang disampaikan sangat ringkas tidak lebih dari tiga ${ }^{51}$ atau delapan menit $^{52}$ setiap episodenya. Beberapa episode tersebut dapat dijumpai dengan mudah pada platform YouTube. Hal penting yang juga menjadi kelebihan program tafsir singkat ini adalah penggunaan bahasa resmi (fușhā) dalam penyampaiannya. Bahasa Arab yang digunakan sehari-hari di Mesir memiliki aksen dan logat yang sedikit berbeda dengan bahasa Arab resmi sebagaimana yang digunakan oleh AlQur'an. Bagi orang-orang non-Arab yang baru belajar bahasa Arab atau tidak pernah tinggal di wilayah Arab, bahasa sehari-hari ('âmmiyyah) tersebut sulit untuk dimengerti. Oleh karenanya, pemilihan bahasa Arab resmi sebagai bahasa yang digunakan dalam program radio ini memungkinkan madrasah tafsir elektronik Mesir diakses oleh lebih banyak orang. ${ }^{53}$ Kelebihan lain dari media radio adalah dapat diakses di mana saja. Tidak heran jika pada awal 2000-an kita dapat mengikuti program tafsir yang disiarkan oleh Idhā'ah al-Qur'ān al-Karìm ini dari atas

51 Idhā'at al-Qur'ān al-Karīm min al-Qāhirah, Wamdah Tafsìriyyah (Kairo, 2018), https://youtu.be/ile3ufzKA_w, diakses 6 Agustus 2020.

52 Muhandis Ibrāhīm MathTube, Al-Syaykh Muhammad Sayyid Țanțāwī Ma 'a al-Qur'ān al-Karīm alTafsir al-Mubassat (Kairo, 2020), https://youtu.be/WGVZFvA_Ux8, diakses 6 Agustus 2020.

53 Dari pengalaman penulis selama tinggal empat tahun di Mission City (Madīnat al-Bu 'üth) Kairo bersama pelajar dan mahasiswa dari berbagai negara lain, program Wamḍah Tafsīinyyah yang disiarkan oleh Idhā'at alQur'ān al-Karīm merupakan salah satu program radio paling populer di Madīnat al-Bu'ūth. Saat itu adalah antara tahun 2002-2006. Salah satu alasannya adalah bahasa yang mudah dimengerti dan tidak terlalu bertele-tele. angkutan umum seperti bus. Dengan begitu madrasah tafsir dalam pengertian ini mulai merambah wilayah-wilayah yang mungkin sebelumnya tidak terbayangkan sebagai tempat untuk belajar memahami Al-Qur'an.

Selain radio, media elektronik televisi juga turut serta dalam memperluas lingkup madrasah tafsir di Mesir. Secara rutin program tafsir Al-Qur'an yang diasuh oleh beberapa tokoh tafsir terkemuka ditayangkan oleh saluran televisi Mesir. Syeikh Muhammad Mutawallī al-Sha'rāwī adalah salah satu narasumber dari program tafsir yang ditayangkan oleh televisi Mesir. Sejak 1977 hingga wafatnya pada 1998 al-Sha'rāwī rutin mengisi program televisi Khawātir hawla al-Qur'ān. ${ }^{54}$ Tafsir yang disampaikan dalam program televisi inilah yang nantinya dikumpulkan dan diterbitkan menjadi Tafsīr al-Sha 'rāwī̄. ${ }^{55}$

Sedikit berbeda dengan al-Sha'rāwī yang murni memulai tafsirnya pada media televisi, syeikh Muhammad Sayyid Țanțāwī justru mengasuh program tafsir pada saluran televisi Nīl al-Thaqāfiyyah berbasis pada karya tafsirnya al-Tafsìr alWasiț.56 Dalam program televisi tersebut

${ }^{54}$ Pink, Muslim Qur'ânic Interpretation Today Media, Genealogies and Interpretive Communities, 101.

${ }^{55}$ Sebenarnya al-Sha'rāwī tidak menganggap karyanya sebagai sebuah tafsir. Dia hanya menyebutnya sebagai khawātir (refleksi) atas Al-Qur'an yang dibacanya. Namun, jika merujuk pada definisi tafsir yang ditawarkan oleh al-Zarqānī, apa yang disebut sebagai refleksi oleh alSha'rāwī dapat diklasifikasikan sebagai tafsir. Hal tersebut sesuai dengan makna tafsir sebagai bentuk usaha manusia untuk memahami makna Al-Qur'an sesuai dengan tingkat kesanggupan masing-masing orang. Muḥammad Mutawallī al-Sha' rāwī, Tafsīr al-Sha 'rāwwì (Kairo: Akhbār al-Yawm, 1991), 9; Abd al-'Aẓ̄̂m al-Zarqānī, Manāhil al'Irfān fì 'Ulūm al-Qur'ān (Beirut: Dār al-Kutub al'Ilmiyyah, 2003), vol.2: 4.

56 Proses pengambilan dan perekaman gambar serta suara untuk program tafsir televisi yang diasuh oleh Grand Syeikh Sayyid Ṭanțāwī ini dilaksanakan rutin setiap pekan. Proses tersebut dimulai setelah salat Jumat berjamaah hingga menjelang waktu salat Asar di masjid Mission City putra. Mayoritas peserta dari pengajian tersebut adalah para pelajar dan mahasiswa asing yang tinggal di Mission City. Penulis adalah salah satu peserta 
Ulya Fikriyati, Evolusi Madrasah Tafsir al-Qur'an di Mesir: Penelusuran... |135

Syeikh Ṭanțāwī membaca tafsir yang telah ditulisnya kemudian menerangkannya secara lebih luas. ${ }^{57}$

Demikianlah, radio dan televisi semakin membuka cakupan madrasah tafsir Mesir. Hal ini tentunya memiliki nilai plus dan minus sekaligus. Nilai plus dari ekspansi madrasah tafsir via media elektronik memungkinkan terjangkaunya kalangan yang lebih luas dalam proses pemahaman Al-Qur'an. Madrasah tafsir dapat diikuti di manapun oleh siapapun. ${ }^{58}$ Sedangkan nilai minusnya dapat disederhanakan menjadi beberapa hal. Pertama, pemahaman parsial atas ayat-ayat Al-Qur'an. "Murid" dari madrasah tafsir elektronik hanya bisa mendapatkan tafsir yang terbatas, sesuai dengan apa yang disampaikan secara singkat dalam program siaran tersebut. Kedua, tidak adanya komunikasi aktif antara guru dan murid menjadi masalah lain ketika pendengar kurang mengerti apa yang disampaikan oleh narasumber di radio maupun televisi. Ketiga, pendengar hanya mengenal satu pemaknaan yang menjadi mainstream negara. Hal tersebut disebabkan negara atau lembaga otoritatif tertentu memegang kendali atas cara pandang yang berkembang dan disebarluaskan di wilayahnya termasuk pada media elektronik. Jika negara yang bersangkutan menganut paham inklusif tentunya tidak menjadi masalah. Jika sebaliknya, ketika negara menganut paham eksklusif, tentunya akan menjadi

tetap yang mengikuti proses perekaman acara televisi tersebut selama kurang lebih satu tahun pada 2005.

57 Rekaman dari salah satu program televisi tersebut diunggah ulang pada platform YouTube oleh Channel Faḍ̄lat al-Imām al-Akbar Muḥammad Sayyid Ṭantāwī, alAyat 121 li Sūrat Āli 'Imrān (Kairo, 2012), https://youtu.be/4OTPjWGUGvY.

58 Pada era sebelumnya, untuk mempelajari tafsir AlQur'an, seseorang harus meluangkan waktu mendatangi berbagai ruwāq di serambi-serambi masjid, katātīb dan para tokoh yang dianggap ahli dalam bidang tafsir. Namun setelah masuknya media elektronik sebagai media penyampaian tafsir Al-Qur'an, seseorang hanya perlu menyalakan radio atau televisi dan dapat mengikuti pelajaran tafsir yang disiarkan oleh program tersebut. tantangan tersendiri. Terlepas dari kelebihan dan kekurangan yang dimilikinya, media elektronik harus diakui telah berperan besar dalam tumbuh kembang madrasah tafsir di Mesir.

\section{Fase Kontemporer}

Fase kontemporer merupakan fase ketiga pada madrasah tafsir Mesir. Hal paling dasar yang membedakan fase kontemporer dengan fase transisi adalah penggunaan media digital yang menggabungkan antara teknologi komputer dan teknologi internet.

\section{Media Digital dalam Madrasah Tafsir Mesir}

Media digital merupakan hal baru dibanding media analog yang menyimpan suatu sesuai dengan format aslinya. Media digital menyimpan suatu data dengan cara mengkonversi data menjadi susunan kode biner yang terdiri dari angka 1 dan 0 menjadi sebuah data yang dapat disimpan dalam komputer. ${ }^{59}$ Ditemukannya internet pada pertengahan abad 20 menjadikan teknologi komputer mengalami lompatan hebat. ${ }^{60}$ Berbagai belahan dunia yang dahulunya dapat didekatkan dengan dengan telegram dan telepon, menjadi terasa lebih dekat dengan keberadaan internet. Hal-hal yang terjadi jauh di dunia nyata dapat disaksikan seakan terjadi langsung di depan mata dan bisa saling berinteraksi secara virtual melalui media

59 Wendi Hui Kyong Chun and Braxton Soderman, "Digital Media, History Of," dalam The Internasional Encyclopedia of Communication, ed. Wolfgang Donsbach (New Jersey: John Wiley \& Sons, 2011), 2.

60 Proyek internet sebenarnya sudah dimulai sejak 1930an. Akan tetapi proses pengembangan dan penyempurnaan internet memakan waktu yang tidak sebentar. Sekitar tahun 1970 internet baru dianggap muncul di Amerika Serikat. Pada awalnya, internet ditemukan untuk melengkapi kebutuhan militer Amerika Serikat melawan Rusia. Lambat laun, internet dibuka untuk publik dan digunakan untuk berbagai hal di luar kepentingan militer dan menjadi sulit dikontrol penggunaannya sejak 1990-an. Brian Winston, Media Technology and Society A History: from the Telegraph to the Internet (London, New York: Routledge, 1998), 325. 
digital dan koneksi internet. Seluruh dunia seakan berubah menjadi satu desa kecil yang dapat saling melihat dan memantau satu sama lain. Istilah global village yang dipopulerkan oleh McLuhhan menemukan konteksnya yang lebih luas.

Di Mesir, internet sudah mulai digunakan secara luas sejak $1992 .{ }^{61}$ Sayangnya, akses internet di Mesir masih tergolong kecil. Dari 68 juta penduduk, hanya sekitar 500 ribu penduduk saja yang memiliki fasilitas dan kemampuan untuk mengoperasikan komputer serta menikmati fasilitas internet pada $2002 .^{62}$ Pada 2019, pengguna internet di Mesir melonjak menjadi 5,1 juta. ${ }^{63}$

Di tengah perkembangan internet yang melonjak dari tahun ke tahun, madrasah tafsir Mesir mulai mengikuti tren. YouTube adalah salah satu platform yang memfasilitasi evolusi madrasah tafsir Mesir via media digital. Ada dua jenis konten media digital dalam madrasah tafsir Mesir saat ini. Jenis pertama adalah unggahan ulang dari pengajian atau program televisi yang berisi tafsir ayat-ayat Al-Qur'an pada era elektronik dan jenis kedua adalah unggahan baru yang memang benar-benar dibuat pada era digital (pasca 1992). Salah satu contoh dari media pertama adalah saluran resmi tafsir al-Sha' rāwi ${ }^{64}$ Sedangkan untuk media yang kedua tidak terhitung banyaknya. Dari berbagai

\footnotetext{
$61 \quad$ "Al-Internet Fì Mișr," https://www.marefa.org/الإنترنت_في_مصر, Agustus 2020.

62 Data tersebut adalah pada 2002, atau sepuluh tahun setelah internet digunakan pertama kali di Mesir. Deborah Wheeler, "Islam, Community and the Internet: New Possibilities in the Digital Age," Interface: The Journal of Education, Community and Values 2, no. 2 (2002): 19.

${ }^{63}$ Wizārat al-Ittișālāt wa Tiknūlūjiyā al-Ma'lūmāt, "Rakā'iz Ișlāḥ Q Qițā' al-Ittișālāt," 2019, http://www.mcit.gov.eg/Ar/TeleCommunications/Telecom _Act_Law/Telecom_Reform_Milestones, diakses pada 7 Agustus 2020.

64 "Al-Qanāt al-Rasmiyyah li Faḍilat al-Shaikh Muhammad Mutawallī al-Sha 'rāwī” (Kairo: https://www.youtube.com/c/AlsharawiOfficial, Agustus 2011), diakses 9 Agustus 2020.
}

channel yang mengudara dan menafsirkan ayat-ayat Al-Qur'an dapat dibuat klasifikasi berdasarkan dua hal. Pertama, madrasah tafsir yang sesuai dengan arus utama (mainstream) otoritas keagaamaan Mesir (yang berada di tangan Al Azhar) dan channel yang berada di luar atau dianggap berlawanan dengan arus utama.

Di antara madrasah tafsir digital yang searus dengan mainstream otoritas keagamaan di Mesir adalah Majlis al-Tafsīr yang diunggah secara rutin setiap pekan oleh channel dmc sejak 7 Juli 2017.65 Narasumber dari Majlis al-Tafsìr adalah alShaykh Khālid al-Jundī dan al-Shaykh Ramaḍān 'Abd al-Mu'izz dengan dua orang pemandu. Dalam penyampaiannya, madrasah ini menggunakan bahasa Arab sehari-hari ('āmmiyyah) yang menunjukkan bahwa target yang disasar adalah masyarakat umum. Materi yang yang ditafsirkan dimulai dengan surah alFātihah dan hingga saat tulisan ini dibuat (Agustus 2020) sampai pada pembahasan QS. Āli ‘Imrān [3]: 21.66

Sumber digital lain yang juga aktif mengunggah tafsir ayat-ayat Al-Qur'an di mesir adalah channel Amr Khaled dalam seri Khawāțir Qur'āniyyah. Khaled sudah memulai tafsirnya sejak 2009 dengan membahas tafsir surah al-Fātihah. ${ }^{67}$ Dibanding dengan narasumber pada Majlis al-Tafsìr, penyampaian Amr Khaled terkesan tidak hanya menafsirkan AlQur'an, tetapi lebih menekankan sisi motivasi untuk para audiennya. Gaya motivator gaul tersebut besar kemungkinan

\footnotetext{
${ }^{65} \mathrm{dmc}$, "La'allahum Yafqahūn Halaqah al-Khamīs 67-2017- Majlis al-Tafsīr 'Tafsīr Sūrat al-Fātihah"” (Kairo, 7 Juli, 2017), https://youtu.be/pDfXT8NKTvQ, diakses 9 Agustus 2020.

${ }^{66} \mathrm{dmc}$, "La'allahum Yafqahūn Majlis al-Tafsīr 'Sūrat Āli 'Imrān al-Āyah 21 'Halaqah al-Khamīs 16-7-2020-" (Kairo, 17 Juli, 2020), https://youtu.be/dLBdHQBStHA, diakses 9 Agustus 2020.

67 Amr Khaled, "Sūrat Al-Fātiḥah-Khawāṭir Qur'āniyyah-'Amr Khālid” (Kairo, July 16, 2009), https://youtu.be/Scl7OtA0JLw.
} 
Ulya Fikriyati, Evolusi Madrasah Tafsir al-Qur'an di Mesir: Penelusuran... |137

disebabkan oleh latar belakang Amr Khaled sebagai influencer anak muda di dunia nyata. Dia juga dikenal sebagai “Da'i dengan pakaian kasual". ${ }^{68}$ Sebelum media digital menjamur, Amr Khaled telah dikenal sebagai salah satu penulis buku self-help di Mesir.

Dari kelompok di luar mainstream otoritas keagamaan, dapat disebut nama Islam Behery. Berbeda dengan beberapa madrasah tafsir digital yang biasanya memulai tafsirnya dari surah al-Fātiḥah, Islam Behery memulai dari beberapa hal mendasar terkait ilmu tafsir. Ia membahas tentang bagaimana menafsirkan Al-Qur'an dengan Al-Qur'an sebagaimana yang dilakukan Rasulullah, ${ }^{69}$ permasalahan $n \bar{a} s i k h$ mansūkh, ${ }^{70}$ dan topik-topik ilmu tafsir lain, baru membahas tafsir dari ayatayat Al-Qur'an. Islam Behery sempat dipenjara karena meragukan kredibilitas hadis-hadis yang sering digunakan untuk menafsirkan Al-Qur'an dan mempertanyakan hal-hal yang dianggap taken for granted dalam Islam. ${ }^{71}$

Tradisi kepemerintahan ala militer di Mesir masih berlaku pada era digital. Jika pada beberapa negara diberlakukan hukum sensor atas konten-konten digital yang tidak selaras dengan arus utama yang

${ }^{68}$ Ashraf "Abd al-Hamīd, “"Amr Khālid min Najm Dīn̄i li Muthār Intiqād wa Limādhā Ab'ada 'an Miṣr," al Arabiya, September 2017, https://www.alarabiya.net/ar/arab-and-

wمرو-خالد-من_نجم-ديني_لمثار -انتقاد-world/egypt/2017/09/05

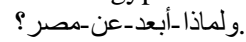

69 Ten TV, “Kayf Nufassir al-Qur'ān bi al-Qur’ān kamā Fa'ala al-Rasūl" (Kairo, November 7, 2018), https://www.youtube.com/watch?v=3LblYvgKPlg, diakses 8 November 2020.

70 Ten TV, “al-Ghazālī Iftarạ̣ anna al-Sunnah Tansakh al-Qur'ān wa Hādhā Ghayr Ma'qūl” (Kairo, March 19 , 2019),

https://www.youtube.com/watch?v=pu5CzlMLKtk, diakses 9 Agustus 2020.

${ }^{71}$ Ahram Online, "Egyptian Court Sends TV Host Islam Behery to Jail for One Year Over Blasphemy," Ahram Online, 29 Desember 2015, http://english.ahram.org.eg/NewsContent/1/64/177654/Eg ypt/Politics-/Egyptian-court-sends-TV-host-Islam-Beheryto-jail-.aspx, diakses 9 Agustus 2020. dianut oleh negara, maka Mesir memberlakukan hukuman fisik penjara bagi akun yang dianggap melampaui batas. Namun ada perbedaan mendasar antara era digital dan sebelumnya. Pada era media cetak dikenal istilah "pembredelan" buku-buku di luar mainstream dan penjatuhan vonis penjara, maka pada era digital yang terjadi hanya pada vonis penjara. Konten-konten yang dianggap berlawanan dengan tafsir-tafsir mainstream masih dapat diakses dengan leluasa. Meski penjatuhan vonis penjara patut disesalkan, tetapi izin akses atas pemikiran-pemikiran yang berbeda layak diapresiasi. Setidaknya, hal tersebut menjadi bukti sejarah bahwa madrasah tafsir Mesir tidak hanya melahirkan satu arus pemikiran, tetapi juga arus-arus lain yang meniscayakan dinamika intelektual semakin berkembang dan dewasa.

\section{SIMPULAN}

Madrasah tafsir Mesir telah ada sejak era Sahabat dan Tabiin dimulai dari penaklukan Mesir oleh Panglima 'Amr ibn al-'Ās pada masa kepemerintahan 'Umar ibn al-Khațāāb. Di awal kelahirannya, madrasah tafsir Mesir sangat terpengaruh oleh madrasah tafsir Makkah. Salah satu alasannya adalah karena para pioner madrasah tafsir Mesir merupakan murid dari Ibn 'Abbās atau pernah berguru di madrasah Makkah. Namun demikian, kultur keberagaman dan keterbukaan Mesir melahirkan banyak aliran dan corak tafsir.

Evolusi media pada madrasah tafsir Mesir dapat dipetakan menjadi tiga fase utama. Ketiga fase tersebut ialah fase klasik, fase transisi dan fase kontemporer. Fase klasik menggunakan dua media tradisional: lisan dan tulisan. Fase transisi mulai melibatkan teknologi yang lebih rumit yaitu media cetak dan elektronik. 
Fase ketiga adalah fase kontemporer yang menggunakan media digital.

Hal penting yang patut diingat ialah bahwa setiap fase pada proses evolusi media dalam madrasah tafsir Mesir tidak benar-benar terputus dan meninggalkan fase sebelumnya. Sebaliknya, setiap fase baru yang datang berperan sebagai penambah dan pelengkap dari varian media yang telah ada sebelumnya. Hingga tulisan ini dibuat, media lisan melalui hafalan, tulisan tangan, buku cetak, siaran radio dan televisi tetap diminati di samping maraknya media digital baik yang berbentuk visual (semisal buku digital), audio (rekaman suara digital), maupun audio visual.

\section{DAFTAR PUSTAKA}

'Abd al-'Aẓim, 'Abdullāh. Wamḍh Tafsìriyyah-Idhā'at al-Qur'ān alKarìm-Min al-Qāhirah al-Syaykh. Kairo, 2019. https://youtu.be/DSDYisaq_lo.

'Abd al-Hamīd, Ashraf. “'Amr Khālid min Najm Dīn̄̄ li Muthār Intiqād wa Limādhā Ab'ad 'an Mișr." $A l$ Arabiya, September 5, 2017. https://www.alarabiya.net/ar/araband-world/egypt/2017/09/05/-عمرو-201/20 خالد_من_نجم-ديني_لمثار _انتقاد_ولماذا_أبعد_عن-

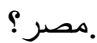

'Abduh, Ibrāhīm. Tārīkh al-Ṭibā'ah wa alȘahafah fì Miṣr Khilāl al-Hamlah alFaransiyyah 1798-1801 M. Jamāmīz: al-Mațba'ah al-Namūdhajiyyah, 1949.

Abdul-Raof, Hussein. Schools of Qur'anic Exegesis. Oxon: Routledge, 2013.

Abu Rabi', Ibrahim. The Blackwell Companion to Contemporary Islamic Thought. Oxford: Blackwell Publishing, 2006.
Abū Shuhbah, Muhammad. Al-Isrā'îliyyāt wa al-Mawdī' 'àt fì Kutub al-Tafsīr. Kairo: Maktabah al-Sunnah, 2003.

'Ādil, Aḥmad. "Assasahā Shā'ir 'al-Nahr al-Khālid'... Idhā'at al-Qur'ān alKarīm 'Mi'rāj al-Īmān 'abra alAthīr.'” Al-Ahrām, March 25, 2018. http://gate.ahram.org.eg/News/1855 706.aspx.

Ahram Online. "Egyptian Court Sends TV Host Islam Behery to Jail for One Year Over Blasphemy." Ahram Online, Desember 2015. http://english.ahram.org.eg/NewsC ontent/1/64/177654/Egypt/Politics/Egyptian-court-sends-TV-hostIslam-Behery-to-jail-.aspx.

Anonim, “Al-Internet F̄̄ Mișr," t.th. https://www.marefa.org/

$$
\text { الإنترنت_في_مصر }
$$

Al-Anșārī, Nāṣir. Al-Mujmal fī Tārīkh Miṣr al-Nuzum al-Siyāsiyah wa alIdāriyyah. Kairo: Dār al-Syurūq, 1993.

Al-'Asqalānī, ibn Ḥajar. Tahdhīb Al-Tahdhīb. Kairo: Dār al-Ḥadīth, 2002.

Badan Pengembangan dan Pembinaan Bahasa. "mad.ra.sah" KBBI $V$. kbbi.kemdikbud.go.id, 2016. kbbi.kemdikbud.go.id.

Al-Baghdādī, Al-Khatīb. Talkhīṣ alMutashābih fi al-Rasm wa Himāyah mā Ashkala Minhu 'an Bawādir al-Tașhīf wa al-Wahm. Damaskus: Sakīnah alShihābī, 1985.

Al-Barrī, 'Abdullāh Khūrshīd. Al-Qur'ān wa 'Ulūmuh fì Miṣr (20 H - 358 H). Kairo: Dār al-Ma‘ārif, 1970. 
al-Ka' bī, 'Abd al-Karīm. Mawsū 'āt al-Tārīkh al-Islāmī 'Așr al-Khulafä' al-Rāshidīn. Amman: Dār Usāmah, 2009.

Channel Faḍilat al-Imām al-Akbar Muhammad Sayyid Tanțāwī. Al$\bar{A}$ yat $121 \mathrm{Li}$ Sūrat Āli 'Imrān. Kairo, 2012.

https://youtu.be/4OTPjWGUGvY.

Chun, Wendi Hui Kyong, and Braxton Soderman. "Digital Media, History Of." dalam The Internasional Encyclopedia of Communication, edited by Wolfgang Donsbach. New Jersey: John Wiley \& Sons, 2011.

Al-Dhahabī, Muhammad Ḥusayn. Al-Tafsīr wa al-Mufassirūn. Kairo: Dār Ihyā' al-Turāth al-'Arabī, 1976.

Al-Dhahabī, Muḥammad ibn Aḥmad. Tadhkirat al-Huffāz. Beirut: Dār alKutub al-'Ilmiyyah, 1998.

dmc. "La'allahum Yafqahūn Ḥalaqah alKhamīs 6-7-2017- Majlis al-Tafsīr ‘Tafsīr Sūrat al-Fātiḥah.'” Kairo, Juli 7 , 2017. https://youtu.be/pDfXT8NKTvQ.

- - . "La'allahum Yafqahūn Majlis alTafsīr 'Sūrat Āli 'Imrān al-Āyah 21 'Halaqah al-Khamīs 16-7-2020-." Kairo, Juli 17, 2020. https://youtu.be/dLBdHQBStHA.

Fawaid, Ah. "Isu-Isu Polemis dalam Diskursus ‘Ulūm al-Qur'ān di Mesir Kontemporer." Tesis, UIN Syarif Hidayatullah, 2008.

Fikriyati, Ulya. “Madrasah Tafsir Virtual di Indonesia Kontemporer: Genealogi Dan Kontestasinya Di Kanal YouTube." dalam Tafsir al-Qur'an di
Nusantara, ed. Ahmad Baedowi. Yogyakarta: Ladang Kata, 2020.

Gunaratne, Shelton A. Paper, Printing and the Printing Press. London, New Delhi: Thousand Oaks, 2001.

Görke, Andreas. "Redefining the Borders of Tafsīr: Oral Exegesis, Lay Exegesis and Regional Particularities." dalam Tafsìr and Islamic Intellectual History Exploring the Boundaries of a Genre, edited by Andreas Görke and Johanna Pink, 361-378. Oxford: Oxford University Press, 2014.

Ḥannā, Mīlād. Al-A'midah al-Sab'ah li alShakhșiyyah al-Mișriyyah. Kairo: Nahḍah Mișr, 1999.

Ibn Manzhūr, Jamāl al-Dīn Muhammad. Lisān al-'Arab. Beirut: Dār al-Ṣādir, 2000.

Idhā'at al-Qur'ān al-Karīm min al-Qāhirah. Wamdah Tafsìriyyah. Kairo, 2018. https://youtu.be/ile3ufzKA_w.

'Izzat, Ahmad, ed. Al-Idhā'ah wa alTilifziyyūn Dirāsah fì I'lām al-Sulțah. Kairo: Association for Freedom of Thought and Expression (AFTE), 2012.

Khaled, Amr. "Sūrat al-Fātiḥah-Khawāțir Qur'āniyyah-'Amr Khālid." Kairo, $16 \quad$ Juli, 2009. https://youtu.be/Scl7OtA0JLw.

Al-Khūlī, Amin. Min Hudā al-Qur'ān. Kairo: al-Hay'ah al-Mișriyyah al-'Āmmah li al-Kitāb, 1987.

McLuhan, Marshall. The Medium is the Massage an Inventory of Effect. New York: Gingko Press, 2001. 
Muhandis Ibrāhīm MathTube. Al-Syaykh Muhammad Sayyid Tanțāwō ma'a alQur'ān al-Karìm al-Tafsìr alMubassaț. Kairo, 2020. https://youtu.be/WGVZFvA_Ux8.

Muștafā al-Farrān, Ahmmad. Tafsīr Al-Imām al-Shāfi ‘̄. Arab Saudi: Dār Tadmuriyyah, 2006.

Nirwana, Dzikri. "Peta Tafsir di Mesir Melacak Perkembangan Tafsir alQur'an Dari Abad Klasik Hingga Modern." Jurnal Falasifa 1, no. 1 (March 2010): 27-46.

Pink, Johanna. Muslim Qur'ânic Interpretation Today Media, Genealogies and Interpretive Communities. Bristol: Equinox Publishing, 2019.

- - . "Tradition, Authority, and Innovation in Contemporary Sunnī Tafsīr: Towards a Typology of Qur'an Commentaries from the Arab World, Indonesia and Turkey." Journal of Qur'anic Studies 12 (2010): 56-82.

Pressman, Jessica. Digital Modernism Making It New in New Media. Oxford: Oxford University Press, 2014.

Al-Qanāt al-Rasmiyyah li Faḍilat al-Shaikh Muhammad Mutawallī al-Sha'rāwī. Kairo, Agustus 2011. https://www.youtube.com/c/Alshar awiOfficial Al-Sha'rāwī, Muhammad Mutawallī. Tafsìr alSha 'rāwwī. Kairo: Akhbār al-Yawm, 1991.

Rị̣ā, Muḥammad Rashīd. Mujallad alAwwal min al-Manār. Kairo: AlManār, 1325.
Al-Rūmī, Fahd 'Abd al-Raḥmān. Manhaj alMadrasah al-Andalusiyyah fi al-Tafsìr Sifätuh wa Khașă'isuh. Riyaḍ: Maktabat al-Tawbah, 1997.

Su'ūdī, Umaymah. "Al-Idhā'ah alMișriyyah Shāhid 'alā Tārīkh Mișr." Al-Hay'ah al-'Āmmah li al-Isti 'lāmāt Jumhūriyyat Mișr al-'Arabiyyah, 17 Februari, 2019. https://www.sis.gov.eg/Story/18282 9?lang=ar.

Al-Suyūṭ̂i, Jalāl al-Dīn. Al-Itqān fì 'Ulūm alQur'ān. Kairo: Dār al-Hadīth, 2004.

Tadrus, Fawzi M. "Printing in the Arab World with Emphasis on the Būlāq Press in Egypt." quspace.qu.edu.qa (1982): 61-77.

Al-Ṭanāḥ̄, Maḥmūd Muhammad. "Awā'il al-Mațbū'āt al-'Arabiyyah fī Mișr." dalam Tārīkh al-Tíb̄' 'āh al-'Arabiyyah hattā Intihā' al-Qarn al-Tāsi' 'Ashar. Vol. 1. Abu Dhabi: Cultural Foundation Publications, 1995.

Ten TV. "Al-Ghazālī Iftaraḍ anna alSunnah Tansakh al-Qur'ān wa Hādhā Ghayr Ma 'qūl." Kairo, 19 Maret, 2019. https://www.youtube.com/watch?v $=$ pu5CzlMLKtk.

- - . "Kayf Nufassir al-Qur'ān bi alQur'ān kamā Fa'ala al-Rasūl." Kairo, 7 November, 2018. https://www.youtube.com/watch?v $=3 \mathrm{LblYvgKPlg}$.

Wheeler, Deborah. "Islam, Community and the Internet: New Possibilities in the Digital Age." Interface: The Journal of Education, Community and Values 2, no. 2 (2002): 1-26. 
Ulya Fikriyati, Evolusi Madrasah Tafsir al-Qur'an di Mesir: Penelusuran... |141

Winston, Brian. Media Technology and Society A History: From the Telegraph to the Internet. London, New York: Routledge, 1998.

Wizārat al-Ittișālāt wa Tiknūlūjiyā alMa'lūmāt. "Rakā'iz Iṣlāh Qitāa' alIttiṣālāt," t.th. http://www.mcit.gov.eg/Ar/TeleCo
mmunications/Telecom_Act_Law/T elecom_Reform_Milestones.

Al-Zarkalī, Khayr al-Dīn ibn Mahmūd. AlA 'lām. Beirut: Dār al-'Ilm li alMalāyīn, 2002.

Al-Zarqānī, Abd al-'Aẓīm. Manāhil al-'Irfān fì 'Ulūm al-Qur'ān. Beirut: Dār alKutub al-'Ilmiyyah, 2003. 
142 | Mashdar : Jurnal Studi al-Quran dan Hadis, Vol.2 No.2 2020 (125-142) 